Article

\title{
Interactive Effects of Copper Pipe, Stagnation, Corrosion Control, and Disinfectant Residual Influenced Reduction of Legionella pneumophila during Simulations of the Flint Water Crisis
}

\author{
Rebekah L. Martin 1,2 ${ }^{1}$, Owen R. Strom ${ }^{3}$, Amy Pruden 1(1) and Marc A. Edwards ${ }^{1, *}$ \\ 1 Department of Civil and Environmental Engineering, Virginia Tech, 418 Durham Hall, \\ Blacksburg, VA 24061, USA; hrebek1@vt.edu (R.L.M.); apruden@vt.edu (A.P.) \\ 2 Department of Civil and Environmental Engineering, Virginia Military Institute, Lexington, VA 24450, USA \\ 3 Elson S. Floyd College of Medicine, Washington State University, Spokane, WA 99202, USA; \\ owen_strom@wsu.edu \\ * Correspondence: edwardsm@vt.edu
}

Received: 29 July 2020; Accepted: 31 August 2020; Published: 4 September 2020

\begin{abstract}
Flint, MI experienced two outbreaks of Legionnaires' Disease (LD) during the summers of 2014 and 2015, coinciding with use of Flint River as a drinking water source without corrosion control. Using simulated distribution systems (SDSs) followed by stagnant simulated premise (i.e., building) plumbing reactors (SPPRs) containing cross-linked polyethylene (PEX) or copper pipe, we reproduced trends in water chemistry and Legionella proliferation observed in the field when Flint River versus Detroit water were used before, during, and after the outbreak. Specifically, due to high chlorine demand in the SDSs, SPPRs with treated Flint River water were chlorine deficient and had elevated L. pneumophila numbers in the PEX condition. SPPRs with Detroit water, which had lower chlorine demand and higher residual chlorine, lost all culturable L. pneumophila within two months. L. pneumophila also diminished more rapidly with time in Flint River SPPRs with copper pipe, presumably due to the bacteriostatic properties of elevated copper concentrations caused by lack of corrosion control and stagnation. This study confirms hypothesized mechanisms by which the switch in water chemistry, pipe materials, and different flow patterns in Flint premise plumbing may have contributed to observed LD outbreak patterns.
\end{abstract}

Keywords: flint; Legionella pneumophila; copper; PEX; iron; chlorine; premise plumbing

\section{Introduction}

The Flint Water Crisis began when the City of Flint, Michigan switched from purchasing its long-term Detroit municipal water supply (sourced from Lake Huron) to the local Flint River in April 2014. Although the Flint River water was predictably much more corrosive than Detroit water, no federally-mandated corrosion control program was implemented, resulting in rampant corrosion of lead plumbing and iron water mains, low chlorine residuals, elevated bacteria, and high levels of lead [1-4]. During the summers of 2014 and 2015, Flint also experienced two outbreaks of Legionnaires' Disease (LD), with 91 cases and 12 deaths documented in Genesee County (the county which Flint is located), compared to the 6-13 cases per year and no deaths during 2009-2013 while on Detroit water [1,3,5,6]. The period of Flint River water use was characterized by high levels of LD incidence [6] and L. pneumophila gene marker levels [1] associated with large buildings. However, lower LD incidence associated with residential exposure was noted from August 2015 onwards and our sampling during this period revealed undetectable or very low levels of $L$. pneumophila in residential plumbing $[1,3]$. 
While temporal associations between the switch in water supply with reduced levels of chlorine, high levels of iron, elevated temperature for Flint River water, and the resulting outbreak of LD were predictable based on prior work [7-10], and duly noted for the Flint outbreak [1,3,5], precise patterns of the outbreak in relation to large health care facilities versus residential single family homes are still the subject of scientific and public interest $[5,11]$.

We recently examined L. pneumophila growth in simulated glass water heaters with either cross-linked polyethylene (PEX) or copper pipe, Detroit tap water (sourced from Lake Huron) or treated Flint River water, and an initial influent $\mathrm{pH} 7.3$ with continuous mixing representing hot water recirculation often present in large buildings [12]. After one year, very high levels of L. pneumophila (2.6-3.0 $\log \mathrm{CFU} / \mathrm{mL}$ ) were observed in all treated Flint River water conditions with PEX pipe and with copper pipe when there was even low levels of phosphate corrosion control present $\left(2.9 \log _{10} \mathrm{CFU} / \mathrm{mL}\right)$. By contrast, all treated Flint River water conditions with copper pipe and no phosphate corrosion control had 1-2 log lower levels of L. pneumophila, likely due to biotoxicity of copper, as directly evidence by an inverse correlation $\left(\mathrm{R}^{2}=0.85-0.95\right)$ between L. pneumophila and measured soluble copper or $\mathrm{Cu}^{+2}$ [12].

Premise plumbing, and its resident microbiome, is highly sensitive to variation in pipe material, $\mathrm{pH}$, disinfection conditions, and stagnation. All of these factors can produce important synergistic or antagonistic effects [13]. For example, a 0.5-unit higher $\mathrm{pH}$ in the influent, would be expected to reduce bacteriostatic effects of copper pipe on resident microbes due to reduced concentrations of $\mathrm{Cu}^{+2}$ and soluble copper [14,15]. Likewise, complete stagnation has sometimes been associated with greatly reduced growth of Legionella versus either completely-mixed (i.e., water recirculation) or more frequent flow [16-19] conditions, whereas the opposite effect is expected if the water has high levels of disinfectant or very high temperature [20]. The presence of free chlorine has also been associated with lower levels of Legionella in general [21-23] and with LD incidence, in particular, during the Flint Water Crisis $[1,3,5]$. Thus, it is of interest to evaluate the extent to which recent phenomena observed to be at play in Flint's premise plumbing [12] hold true under a broader range of relevant conditions. Specifically, conditions with a higher influent $\mathrm{pH}$ (7.8-8.5), stagnation (which is more common in residences than large building hot water systems), and the free chlorine levels representative of before, during, and after the Flint Water Crisis.

Here, we evaluated how the corrosive treated Flint River water and the less corrosive Detroit tap water interacted with unlined iron water mains, and then subsequently with the premise plumbing pipe materials into which that water flowed, to influence levels of disinfectant and the propensity for Legionella growth (Figure 1). The overarching hypothesis was that the lack of corrosion control of Flint River water would cause higher iron and lower chlorine after contact with unlined iron pipe mains (Figure 1), creating conditions less likely to disinfect Legionella when this water flowed into stagnant PEX plumbing. Copper pipe, which has the potential to either catalyze chlorine decay and thereby hinder disinfection [24-26], or release antimicrobial soluble copper ions and enhance disinfection, was compared to a control with PEX pipe for all conditions. The expectation was that Legionella would survive best in treated Flint River water with PEX versus copper due to little or no chlorine delivery, but that the converse would be true in Detroit tap water if copper pipe catalyzed chlorine decay and the high levels of corrosion control would virtually eliminate passive disinfection by copper (Figure 1). This study provides important insight into interactive effects of water chemistry and pipe material in affecting the trajectory of community-wide LD outbreak. 


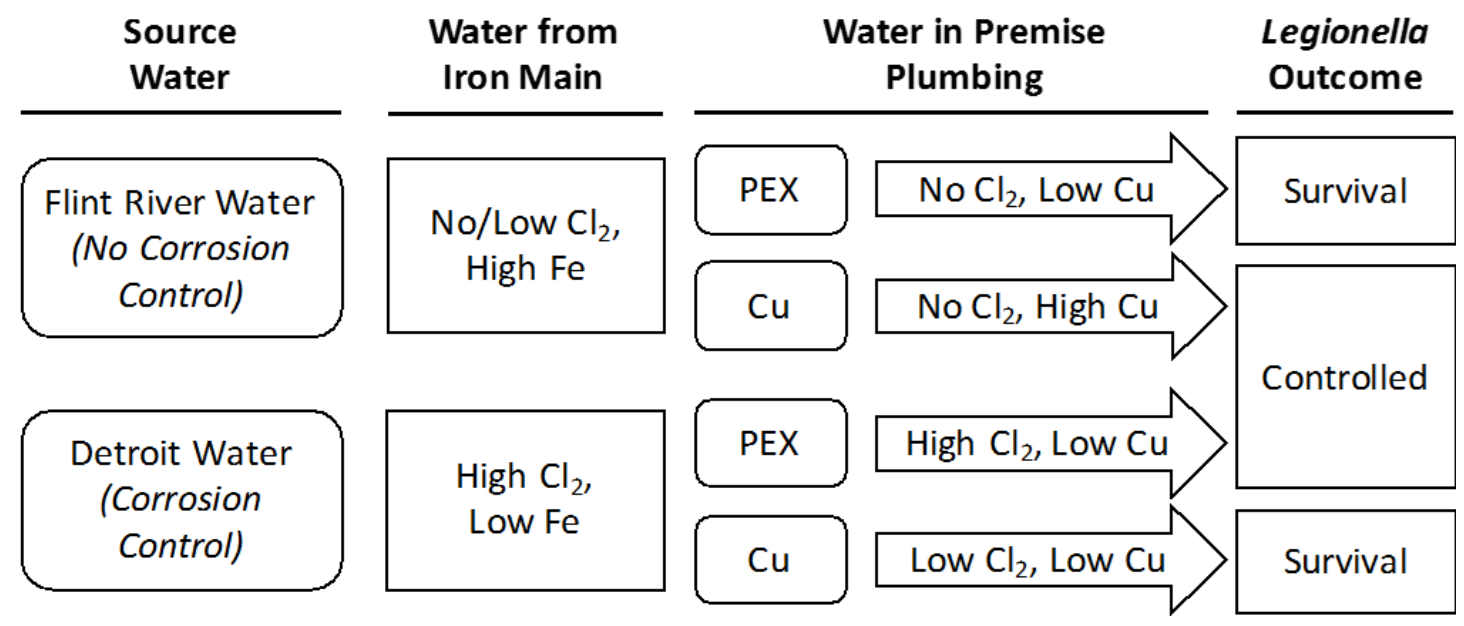

Figure 1. Experimental framework and specific hypotheses for this study. Corrosivity of the municipal water supply influences levels of chlorine and iron in the water delivered to the premise plumbing. Premise plumbing materials, cross-linked polyethylene (PEX) or copper $(\mathrm{Cu})$, further alter the water chemistry and overall propensity for Legionella to be controlled or to survive. Corrosion of copper and iron will consume free chlorine, whereas plastic materials have little or no chlorine demand. Corrosive water will also release soluble copper ions from copper pipe, especially in stagnant premise plumbing conditions. Elevated levels of either copper or chlorine can control Legionella.

\section{Materials and Methods}

\subsection{Source Water Treatment}

Raw water was directly collected from the Flint River at GPS coordinates 43.018230, -83.693944. Lake Huron-sourced drinking water (Detroit tap water) was collected after $>5$ min flushing from the tap of a residential Flint home. Raw Flint River water and Detroit tap water were both collected on 18 August 2016, 21 September 2016, 11 October 2016, 21 November 2016, and 27 January 2017 and express shipped to Blacksburg, Virginia in 30-L containers. Additional raw Flint River water samples were collected and shipped express on 8 February 2017 and 11 March 2017. All collected water was stored at $4{ }^{\circ} \mathrm{C}$ prior to preparation for experiments.

Water treatments applied to raw Flint River water during the crisis were simulated in the laboratory. These included $56 \mathrm{mg} / \mathrm{L}$ ferric chloride for coagulation, $10 \mathrm{~min}$ of stirring for flocculation, $159 \mathrm{mg} / \mathrm{L}$ lime as $\mathrm{Ca}(\mathrm{OH})_{2}$ for softening, followed by another $15 \mathrm{~min}$ of flocculation. The water was subsequently settled for $4 \mathrm{~h}$ and filtered through a column of glass wool to simulate sand filtration. Water treated in this manner was designated as "treated Flint River" water (Figure 2). Working stocks (10-20 L) of treated Flint River water and Detroit tap water were stored at room temperature $\left(23^{\circ} \mathrm{C}\right)$ until the supply was exhausted. 


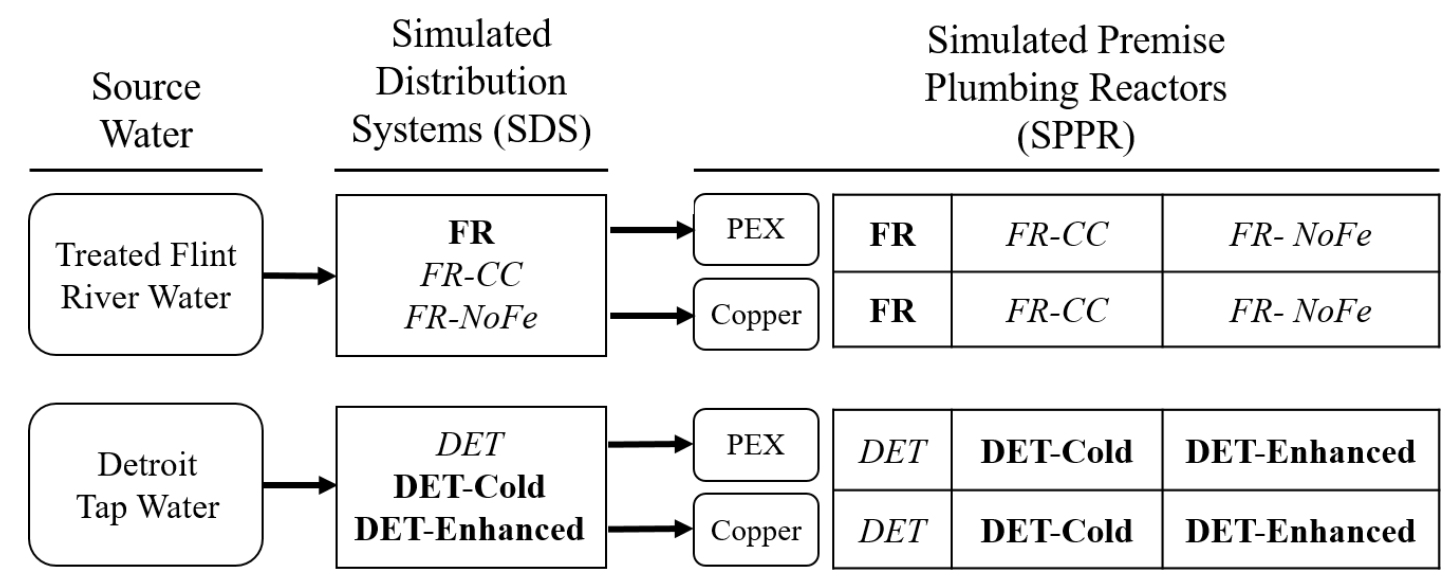

Figure 2. Experimental design from source water to simulated distribution systems (SDSs) to simulated premise plumbing reactors (SPPRs). Source water was treated and stored in 10-30 L batches until fed to SDSs. Each SDS condition was set up in a flask containing $330 \mathrm{~mL}$ of source water, an iron wire (except for $F R$-no $F e$ ), a stir bar, and 3.0 or $3.5 \mathrm{mg} / \mathrm{L}$ chlorine. Bold conditions were designed to replicate scenarios found before (DET-Cold), during (FR), or after the Flint Water Crisis (DET-Enhanced). Conditions in italics were designed to simulate hypothetical scenarios if corrosion control had been implemented or if water had not flowed through unlined iron pipe. After the SDSs simulation was completed, the water was fed to corresponding SPPRs containing either PEX $(n=3)$ or copper $(n=3)$. The total number of SPPRs was 36.

\subsection{Simulated Distribution Systems: Chlorination and Corrosion}

Six SDS conditions served to reproduce distributed waters that either occurred (conditions designated in bold font) under conditions relevant to the Flint Water Crisis or its aftermath or hypothetical scenarios if corrosion control had been implemented or if water had not flowed through unlined iron pipe (conditions designated in italics) (Figure 2). In five of the six conditions, the practical influence of unlined iron distribution system pipe was simulated by addition of an iron wire to flasks mixing each water for $3 \mathrm{~h}$. Treated Flint River water conditions included a condition with the omission of phosphate corrosion control (as was the case during the crisis) (FR), a hypothetical condition if $1 \mathrm{mg} / \mathrm{L}$ as $\mathrm{PO}_{4}-\mathrm{P}$ orthophosphate corrosion control had been implemented (FR-CC), and a condition without any phosphate corrosion control or iron corrosion (i.e., no iron wire) ( $F R-\mathrm{NoFe}$ ) representing some sections of Flint served by newer concrete lined iron or PVC distribution system pipe during the crisis. Detroit tap water conditions examined the pre-crisis effect of Lake Huron-sourced water with lower distribution system temperature (DET-Cold) containing $2.5 \mathrm{mg} / \mathrm{L}$ orthophosphate $\mathrm{PO}_{4}-\mathrm{P}$, the post-crisis water with enhanced doses of chlorine and additional phosphate $(3.5 \mathrm{mg} / \mathrm{L}$ chlorine and $4.0 \mathrm{mg} / \mathrm{L}$ orthophosphate) to assist with system recovery once Flint switched back to Detroit-sourced water (DET-Enhanced), and a hypothetical condition if normal Detroit distribution water with $2.5 \mathrm{mg} / \mathrm{L}$ orthophosphate had been as warm as treated Flint River water during summer months (DET).

\subsection{General SDSs Water Preparation}

Sodium hypochlorite (10\% diluted Clorox ${ }^{\mathrm{TM}}$ bleach, the Clorox Company, Oakland, CA, USA) was added to $330 \mathrm{~mL}$ of each water condition until an initial stable target of $3 \mathrm{mg} / \mathrm{L}$ free chlorine residual was obtained (the only exception being a higher residual of $3.5 \mathrm{mg} / \mathrm{L}$ in DET-Enhanced), followed by the SDSs in $500 \mathrm{~mL}$ glass flasks containing magnetic stir bars and mixing $400 \mathrm{rpm}$ for three hours. In all conditions, except $F R-N o F e$, the presence of iron pipe was simulated in the SDS with a $12 \mathrm{~cm}$ length of $99 \% 2 \mathrm{~mm}$ diameter iron wire (approximately, $7.6 \mathrm{~cm}^{2} \mathrm{Fe}$ surface per liter of water) and orthophosphate was added to achieve corrosion control targets of 1 (FR-CC), 2.5 (DET, DET-Cold), or $4.0 \mathrm{mg} / \mathrm{L}$ (DET-Enhanced). 


\subsection{Premise Plumbing}

\subsubsection{Simulated Premise Plumbing Reactors (SPPRs)}

Following the SDS step, waters were transferred to $100 \mathrm{~mL}$ borosilicate glass bottles (36 total) designed to simulate changes occurring in water as it ages in premise plumbing (SPPR, Figure 2). Each SPPR was equipped with either eight pieces of $20 \mathrm{~mm} \times 10 \mathrm{~mm}$ cross-sectional PEX $(\mathrm{n}=18)$ or solid copper $(n=18)$ pipe material. Pipe coupons had been aged in the bottles for six years in prior experiments, described elsewhere [8-10,27], which provided a benefit of well-aged premise plumbing pipe materials and mature biofilms at the start of the experiment.

\subsubsection{Initializing the SPPRs}

All 36 SPPRs were conditioned prior to the experiment, by dosing a homogeneous aliquot of reactor effluents according to pipe material, followed by an acclimation phase of $50 \%$ water volume changes with treated Flint River water every three days for 101 days. This water change frequency and volume simulated a low use, high-stagnation condition considered to be conducive to Legionella growth in premise plumbing [8]. On Day 14, the SPPRs were inoculated with three environmental L. pneumophila isolates from Flint, MI buildings at a total concentration of 10,000 colony forming units per milliliter $(\mathrm{CFU} / \mathrm{mL})$. The inoculum was composed of a mixture of L. pneumophila serogroup 1 as well as two non-serogroup 1 isolates. Inoculum concentration was determined by optical density readings of L. pneumophila colonies scraped from agar plates, resuspended in Nanopure water, and measured at $600 \mathrm{~nm}$ using a $4500 \mathrm{HACH}$ spectrophotometer (Hach Company, Loveland, CO, USA).

To avoid introduction of Legionella spp. that may have been present in the water shipments once the experiment was in progress, effluent SDS waters were monitored for survival of culturable Legionella prior to their addition to corresponding SPPRs. In no case was detectable culturable Legionella present after chlorination of the water and incubation in the SDSs.

\subsubsection{Water Changes with SDS Conditions}

Following inoculation and a 101-day conditioning period with treated Flint River water, 50\% water changes were performed every 3-4 days for 175 days. SPPRs were reproducibly inverted five times for each water change to resuspend any settled material, and $50 \%$ of the volume was decanted and replaced with water from one of the six SDS conditions (Figure 2). Each of the six SDS conditions were tested in triplicate copper or PEX SPPRs. Reactors were incubated under static conditions at $37^{\circ} \mathrm{C}$ between water changes. Thus, the experimental design included 6 SDS conditions $\times 2$ pipe materials $\times 3$ replicates $=36$ total SPPRs.

Culturable L. pneumophila were enumerated as colony forming units per deciliter (CFU/mL) on Buffered Charcoal Yeast Extract (BYCE) agar (Remel, Lenexa, KS, USA) supplemented with $3 \mathrm{~g} / \mathrm{L}$ glycine, $0.4 \mathrm{~g} / \mathrm{L}$ L-cysteine, 80,000 units/L of polymyxin B sulfate, $0.001 \mathrm{~g} / \mathrm{L}$ vancomycin, and $0.08 \mathrm{~g} / \mathrm{L}$ cycloheximide. Initially, water was directly taken from SPPRs and plated onto BYCE; however, once CFUs dropped below detection of direct plating of $1 \mathrm{~mL}, 50 \mathrm{~mL}$ of effluent SPPR water was filter concentrated using $0.22 \mu \mathrm{M}$ pore size mixed-cellulose ester membranes (Millipore, Billerica, MA, USA) and resuspended in $5 \mathrm{~mL}$ of Nanopure water prior to plating $(1 \mathrm{~mL})$. Water from each reactor was plated in triplicate. Plates were incubated at $37^{\circ} \mathrm{C}$ for 5 days, after which L. pneumophila colonies were counted and $\mathrm{CFU} / \mathrm{mL}$ were calculated. Direct plates with $0.02 \mathrm{CFU} / \mathrm{mL}$ were considered below detection. When no L. pneumophila colonies were detected from $50 \mathrm{~mL}$ concentrates, counts were considered below detection, resulting in a detection limit of $0.001 \mathrm{CFU} / \mathrm{mL}$.

\subsection{Culture Confirmation}

To gain insight into the types of Legionella that persisted through the experiment, colonies visually determined as Legionella and non-Legionella species were picked from plates after 5 days of incubation at $37^{\circ} \mathrm{C}$ for polymerase chain reaction confirmation. Polymerase chain reaction was used 
to confirm Legionella spp. (i.e., genus), L. pneumophila, and serogroup 1 using established primers and protocols [28,29].

\subsection{Water Quality Analyses}

Influent SDSs, effluent SDSs (influent SPPRs), and effluent SPPR waters were analyzed on Days $0,9,20,72,87,126,131$, and 153. Inorganics, including dissolved and particulate iron and copper, were measured by inductively coupled plasma-mass spectrometry (ICP-MS) following $2 \%$ acidification with nitric acid. Total organic carbon (TOC) was measured according to standard method $5310 \mathrm{C}$ using a persulfate-ultraviolet detection by a Sievers Model 5300 C (General Electric Company, Boston, MA, USA). pH was measured using an Oakton 110 series meter (Cole Parmer, Count Vernon Hills, IL, USA).

Free chlorine was measured using a $4500 \mathrm{HACH}$ spectrophotometer (Loveland, $\mathrm{CO}$ ) according to $4500-\mathrm{Cl}$ standard method. To examine the kinetics of chlorine in the various water conditions used in this study, chlorine decay tests were performed on source waters (treated Flint River water and Detroit tap water) in non-reactive glass containers, on SDS water conditions with iron wire according to the experimental design (Figure 2), and after the SDSs waters were added to the SPPRs.

\subsection{Data Analysis}

Statistical tests were performed using R Studio (Version 1.0.153). A Shapiro-Wilk normality test was performed and none of the data were normally distributed. Arithmetic means were calculated for displaying results due to the high proportion of non-detect values in the dataset. Wilcoxon rank sum and Kruskal-Wallis rank sum tests with post-hoc Tukey tests were performed to determine statistical correlations. Wilcoxon tests were used for Legionella culture data (log transformed), pipe material, iron, and copper data, whereas the Kruskal-Wallis test was used to determine significance of chlorine data between SPPRs. Significance was set at a $p$ value $\leq 0.05$.

\section{Results and Discussion}

\subsection{Simulated Treatment and Distribution Reproduced Key Factors of Pre-, During-, and Post-Crisis Flint Water}

\subsubsection{Treated Source Waters Employed in this Experiment}

To recreate water quality conditions in Flint, influent water conditions were simulated by treating raw Flint River water in the lab and collecting Lake Huron-sourced water from a well-flushed tap in Flint post crisis (Detroit tap water). The unaltered $\mathrm{pH}$ of treated Flint River water ranged between 7.84 and 8.57, while Detroit tap water ranged from 7.96 to 8.06, which recreated the stable $\mathrm{pH}$ observed when Flint was using Detroit water and the more variable pH when using Flint River water in 2014 [3,12].

The source water was added in 300-mL aliquots to six glass flasks (3 with Detroit tap water, 3 with treated Flint River water) with iron wire and mixed for $3 \mathrm{~h}$ to simulate six different conditions in distribution systems (SDSs). Just prior to being added to the SDSs, the source waters (treated Flint River water and Detroit tap water) were chlorinated, achieving an initial disinfectant residual of $3.10 \mathrm{mg} / \mathrm{L} \mathrm{Cl}_{2}$ (Table 1 section B). Additional chlorine was added to only the DET-Enhanced SDS condition to achieve a higher average initial residual of $3.80 \pm 0.19 \mathrm{mg} / \mathrm{L}$ (Table 1 section $\mathrm{B}$ ). The possible short-term role of cooler temperature during distribution while on Detroit tap water was tested in this work with the DET-Cold SDS condition, held at an average of $18.3 \pm 1.4{ }^{\circ} \mathrm{C}$ compared to an average $21.8 \pm 1.3^{\circ} \mathrm{C}$ of the other five SDS conditions (FR, FR-NoFe, FR-CC, DET, DET-Enhanced) (Table 1 section $\mathrm{B}, \mathrm{C}$ ). This $\sim 3^{\circ} \mathrm{C}$ difference served to recreate the reported average summer water temperature of $19.9 \pm 2.24{ }^{\circ} \mathrm{C}$ (pre-crisis, Detroit) and $22.6 \pm 2.14{ }^{\circ} \mathrm{C}$ (during crisis, Flint River) (Table 1 section A) [3]. 
Table 1. Relevant Flint Water Crisis data compared to simulated treatment, distribution, and premise plumbing conditions.

\begin{tabular}{|c|c|c|c|c|c|c|c|c|c|c|c|c|c|c|c|}
\hline \multicolumn{4}{|c|}{ A: Flint Water Crisis Field Data * } & \multicolumn{6}{|c|}{ B: Simulated Distribution System Influent ^ } & \multicolumn{6}{|c|}{$\begin{array}{c}\text { C: Simulated Distribution System }\left(\mathrm{T}, \mathrm{Cl}_{2}, \mathrm{Fe}\right) \text { or Simulated Premise } \\
\text { Plumbing Reactor }(\mathrm{Cu}) \text { Effluent }{ }^{+}\end{array}$} \\
\hline Condition & Pre-Crisis & Crisis & Post-Crisis & $\begin{array}{l}\text { DET } \\
\text {-Cold }\end{array}$ & FR & $\begin{array}{c}\text { DET } \\
\text { Enhanced }\end{array}$ & $F R-C C$ & FR-NoFe & $D E T$ & $\begin{array}{l}\text { DET } \\
\text {-Cold }\end{array}$ & FR & $\begin{array}{c}\text { DET } \\
\text {-Enhanced }\end{array}$ & $F R-C C$ & $F R$-NoFe & $D E T$ \\
\hline & & & & 1 & & 2 & & & & 1.4 & & 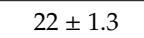 & & & \\
\hline $\begin{array}{l}\text { Chlorine }(\mathrm{mg} / \mathrm{L} \\
\left.\quad \mathrm{Cl}_{2}\right)\end{array}$ & $\begin{array}{c}0.50 \pm \\
0.19\end{array}$ & $\begin{array}{c}0.28 \pm \\
0.24\end{array}$ & $\begin{array}{c}0.38 \pm \\
0.16\end{array}$ & $\begin{array}{c}3.10 \pm \\
0.20\end{array}$ & $\begin{array}{c}3.10 \pm \\
0.21\end{array}$ & $\begin{array}{c}3.80 \pm \\
0.19\end{array}$ & $\begin{array}{c}3.10 \pm \\
0.21\end{array}$ & $\begin{array}{c}3.10 \pm \\
0.21\end{array}$ & $\begin{array}{c}3.10 \pm \\
0.20\end{array}$ & $\begin{array}{c}1.28 \pm \\
0.23\end{array}$ & $\begin{array}{c}0.26 \pm \\
0.23\end{array}$ & $\begin{array}{c}1.87 \pm \\
0.70\end{array}$ & $\begin{array}{c}0.17 \pm \\
0.20\end{array}$ & $\begin{array}{c}1.27 \pm \\
0.49\end{array}$ & $\begin{array}{c}1.07 \pm \\
0.52\end{array}$ \\
\hline $\begin{array}{l}\text { Flushed Total } \\
\text { Iron }(\mu \mathrm{g} / \mathrm{L})\end{array}$ & UNK & $\begin{array}{c}208 \\
(21-340)\end{array}$ & $\begin{array}{c}42.4 \\
(0-130)\end{array}$ & $\begin{array}{c}92.1 \\
(80-110)\end{array}$ & $\begin{array}{c}15.4 \\
(2.0-47)\end{array}$ & $\begin{array}{c}92.1 \\
(80-110)\end{array}$ & $\begin{array}{c}15.4 \\
(2.0-47)\end{array}$ & $\begin{array}{c}15.4 \\
(2.0-47)\end{array}$ & $\begin{array}{c}92.1 \\
(80-110)\end{array}$ & $\begin{array}{c}1300 \\
(490-2500)\end{array}$ & $\begin{array}{c}2300 \\
(590-5200)\end{array}$ & $\begin{array}{c}900 \\
(360- \\
2000)\end{array}$ & $\begin{array}{c}3100 \\
(690-9500\end{array}$ & $\begin{array}{c}15.4 \\
2.0-47)\end{array}$ & $\begin{array}{c}2400 \\
(710-6000)\end{array}$ \\
\hline $\begin{array}{c}\text { Total Copper } \\
(\mu \mathrm{g} / \mathrm{L})\end{array}$ & UNK & $\begin{array}{c}129 \\
(14-380)\end{array}$ & $\begin{array}{c}46 \\
(3.0-140)\end{array}$ & $\begin{array}{c}12 \\
(5.7-20)\end{array}$ & $\begin{array}{c}8.0 \\
(4.1-15)\end{array}$ & $\begin{array}{c}8.0 \\
(5.7-20)\end{array}$ & $\begin{array}{c}8.0 \\
(4.1-15)\end{array}$ & $\begin{array}{c}8.0 \\
(4.1-15)\end{array}$ & $\begin{array}{c}12 \\
(5.7-20)\end{array}$ & $\begin{array}{c}962 \\
(510-1390)\end{array}$ & $\begin{array}{c}2380 \\
(1790-3120)\end{array}$ & $\begin{array}{l}510 \\
(170- \\
1100)\end{array}$ & $\begin{array}{c}1200 \\
(520-2000\end{array}$ & $\begin{array}{c}650 \\
(530-850)\end{array}$ & $\begin{array}{c}880 \\
(640-1400)\end{array}$ \\
\hline
\end{tabular}

* Section (A): Representative chemical mean, \pm standard deviation, (5-95 percentile range where available) for peak Legionnaires' Disease (LD) months of June-September for the indicated stage of the Flint Water Crisis. Representative distribution system temperature data are reported in Rhoads et al. (2017), chlorine data are from monitoring station 6, iron data are from citizen science sampling of flushed water from the same 150 homes in August 2015 (crisis) and August 2017 (post-crisis), and copper water crisis data are from a subset of first draw samples from homes that records indicate had at least partial copper service lines $(\mathrm{n}=79)$. UNK $=$ unknown. ^ Section $(\mathbf{B})$ : Same parameters as in Section (A) were measured in the influent to the SDSs mean (5th-95th percentile) ( $\mathrm{n}=10$ samples over a 10-month period) (Ambient laboratory set point reported for temperature data). Bold conditions SDSs were designed to simulate actual conditions found during the crisis. Conditions in italics were designed to simulate hypothetical scenarios. "DET" conditions received Detroit tap water influent. "FR" conditions received treated Flint River influent. + Section (C): Mean and standard deviation of temperature and chlorine and mean (5th-95th percentile) of iron effluent from SDSs (i.e., influent to the SPPRs) and mean (5th-95th percentile) of copper in the effluent of copper pipe SPPRs. 


\subsubsection{SDSs Chlorine}

The effluent water collected following the 3-h SDSs reaction time (Figure 2) successfully replicated known trends in chlorine residuals observed in the Flint water distribution system before, during, and after the water crisis. To assess inherent chlorine demand prior to the SDSs step, treated Flint River and Detroit tap waters were aliquoted to non-reactive glass containers without iron. The chlorine residual in treated Flint River water dropped from $\sim 3$ to $\sim 1 \mathrm{mg} / \mathrm{L}$ in $180 \mathrm{~min}$, presumably due to relatively high levels of organic matter $(5.2 \pm 0.03 \mathrm{mg} / \mathrm{L} \mathrm{TOC})$, whereas there was little to no decay occurred in the Detroit tap water $(1.2 \pm 0.03 \mathrm{mg} / \mathrm{L} \mathrm{TOC})$ over the same time period (Figure 3A). The addition of iron wire to simulate unlined iron pipe corrosion during distribution further reduced chlorine residuals in conditions with both treated Flint River water and Detroit tap water as influents (Figure 3B). However, while some residual was consistently detected in the Detroit tap water effluents after simulated distribution (DET, DET-cold, DET-Enhanced; $0.5-1 \mathrm{mg} / \mathrm{L} \mathrm{Cl}_{2}$ after 180-min exposure), treated Flint River water conditions (FR, FR-CC, FR-no Fe) generally had no detectable residual (Figure 3B). Condition FR-NoFe is not shown in Figure 3B because no iron wire was added to the SDSs for that condition.

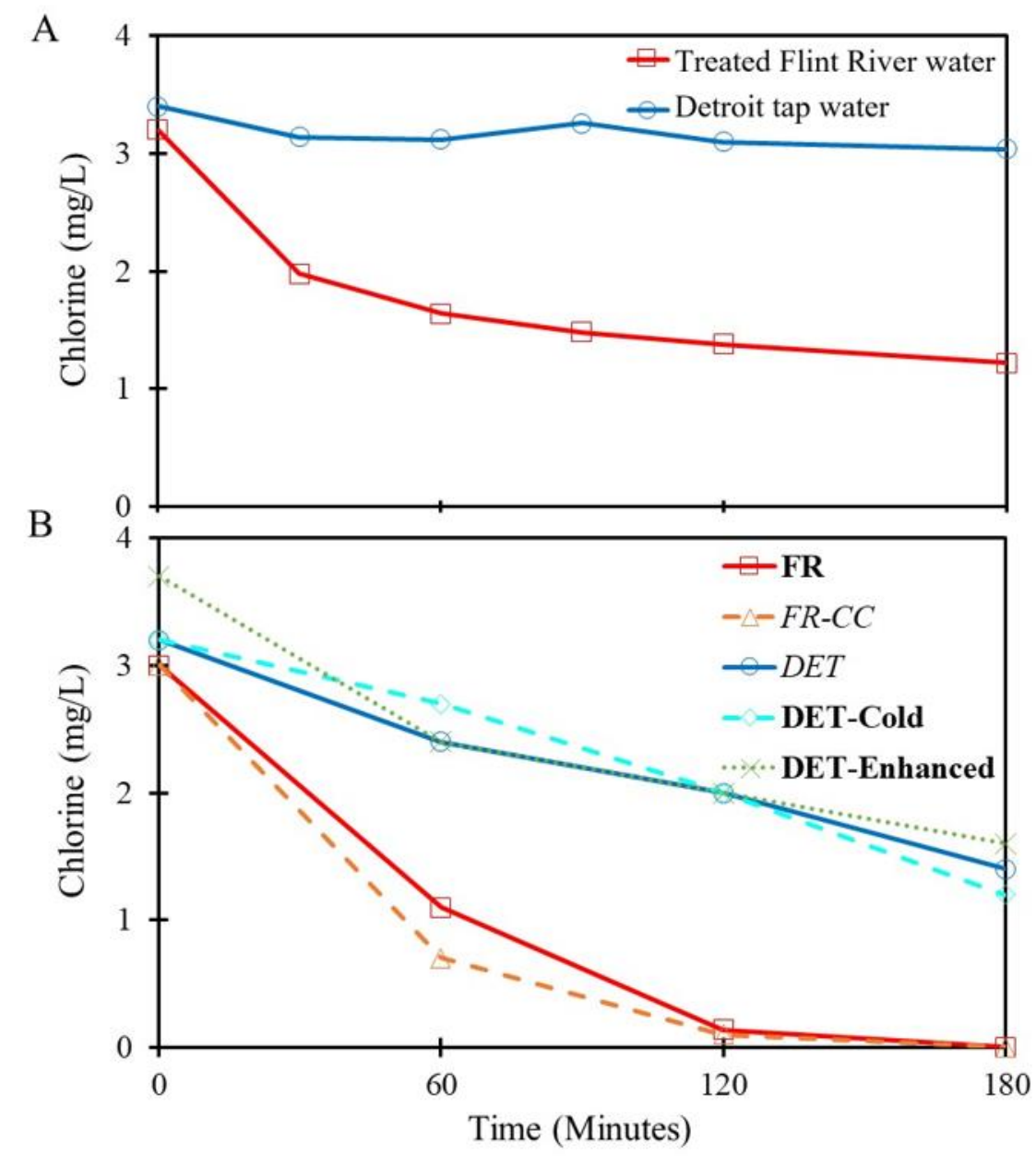

Figure 3. Representative $\mathrm{Cl}_{2}$ decay in source water and simulated distribution systems (SDSs). (A) Control experiment of chlorine decay of treated Flint River and Detroit tap water in non-reactive glass reactors without iron. (B) Representative results in different SDSs conditions: FR, treated Flint river water aged with iron wire; FR-CC, treated Flint River water with added corrosion control and aged with iron wire; DET, Detroit tap water aged with iron wire; DET-Cold, Detroit tap water incubated at cooler temperature with iron wire; DET-Enhanced, Detroit tap water with additional corrosion control and initial elevated chlorine levels. 
While there was variability due to seasonal changes in the source water and variable iron wire corrosion rates throughout the experiment, the mean chlorine concentration $(\mathrm{n}=43)$ after incubation in the SDSs exhibited a general trend of (lowest to highest): $F R-C C \approx \mathbf{F R}<F R-N o F e \approx D E T \approx$ DET-Cold $<$ textbfDET-Enhanced (Table 1). Based on a Kruskal-Wallis rank sum test, the mean chlorine concentrations across the SDS conditions were significantly different ( $p$ value $<2 \times 10^{-16}$ ), while a pairwise post-hoc Tukey test further confirmed specific differences between conditions indicated by a " $<$ " sign in the above trend analysis (all $p$ values $\leq 0.009$ ).

Overall, key expectations were also recreated with respect to known trends resulting from water chemistry and corresponding chlorine residual in SDSs effluent. Specifically, the SDSs successfully reproduced chlorine residuals comparable to those during the crisis of $0.28 \pm 0.24 \mathrm{mg} / \mathrm{L}$ (at Flint city monitoring station 6) [30], compared to levels of $0.26 \pm 0.23 \mathrm{mg} / \mathrm{L}$ in our treated Flint River water simulation (FR condition, Table 1 section C). SDS conditions also successfully simulated pre-crisis (DET-Cold) and post-crisis (DET-Enhanced) high chlorine, with actual values only $1 \mathrm{mg} / \mathrm{L}$ higher than measured during the pre- or post-crisis conditions (Table 1 section C). Both conditions with treated Flint River water and iron present (FR and $F R-C C$ ) occasionally had undetectable chlorine residuals under the conditions tested, whereas $F R-N o F e$ and all conditions with Detroit tap water consistently had a measurable chlorine disinfectant residual following simulated distribution, as hypothesized (Figure 1). Iron has been shown to decay chlorine residual in typical drinking waters [31], but the chlorine decay observed in the SDS step was accelerated beyond what is typical due to the corrosivity of the treated Flint River water and lack of corrosion control.

\subsubsection{SDSs Iron and Corrosion Control}

Known benefits of corrosion control (FR vs. FR-CC; FR vs. DET) in terms of hindered iron release and maintenance of higher chlorine residuals in the actual Flint distribution system (Table 1) were not achieved in these simplistic simulations. Based on a prior study [2], the addition of phosphate corrosion control to treated Flint River water reduced iron weight loss by 5.1 times compared to that observed in treated Flint River water without phosphate, while also reducing chlorine decay rates. Further, iron corrosion rates were 8.6 times lower in Detroit tap water with corrosion control versus treated Flint River water without corrosion control, a trend confirmed by our citizen science field sampling throughout Flint in August 2015 versus August 2017 (Figure 1) [3,5]. However, the corrosion control simulation applied to the SDSs in this study did not produce known significant differences in mean effluent iron (i.e., FR, FR-CC, and DET; Table 1 section C). The only condition with relatively low iron in this work was treated Flint River water without any iron present $(\mathrm{FR}-\mathrm{NoFe})$, in which mean iron was $15.4 \pm 19.4 \mu \mathrm{g} / \mathrm{L}$ compared to the $60.5 \pm 212 \mu \mathrm{g} / \mathrm{L}$ observed in August 2017 flushed water samples collected in Flint (Table 1).

We were aware that the simple approach applied here would not effectively replicate impacts of iron corrosion control, given that phosphate inhibition of iron corrosion and associated chlorine decay can sometimes require 6-12 months to produce expected benefits even under continuous-flow conditions in water mains, and even longer under more stagnant conditions [32,33]. In this seven-month simulation, the iron was only exposed to the water approximately $6 \mathrm{~h}$ each week, which translates into seven days total exposure of iron to the target water over the entire study. Thus, the analysis that follows considers that this particular aspect of the simulation is not representative of what occurred in the field.

\subsection{Simulated Premise Plumbing Reactors Reproduced Key Water Chemistry Trends of Pre-, During, and Post-Crisis Flint Water}

\subsubsection{SPPRs Chlorine}

After the effluents from the SDSs were transferred to the SPPRs, the $50 \%$ water change produced an immediate dilution of chlorine. Beyond dilution, there is an immediate chlorine demand from the 
combination of aged pipe material, pipe surface area, biofilm, and water within each reactor [24,26]. Notably, all SDS conditions, except DET-Enhanced, experienced an immediate chlorine demand within the first $10 \mathrm{~min}$, which exceeded the $50 \%$ loss expected from dilution. FR and FR-CC never received any initial chlorine residual flowing into the SPPRs (Figure 4), whereas FR-NoFe retained a low, but detectable, chlorine residual ( $>0.1 \mathrm{mg} / \mathrm{L}$ ) for a period of $60-120 \mathrm{~min}$ in the PEX SPPRs and 1-10 $\mathrm{min}$ in the copper SPPRs (data not shown). Chlorine was reduced in the Detroit tap water SPPRs to below $0.1 \mathrm{mg} / \mathrm{L}$ within 30-60 min in both PEX and copper SPPRs, while chlorine was maintained above $0.1 \mathrm{mg} / \mathrm{L}$ for up to $120 \mathrm{~min}$ in DET-Cold with PEX (Figure 4) versus just 10-30 $\mathrm{min}$ in the corresponding copper SPPRs. Chlorine residuals in the DET-Enhanced conditions after 120 min were 0.92 and $0.38 \mathrm{mg} / \mathrm{L}$ in the PEX and copper SPPRs, respectively (Figure 3). In some instances, chlorine was still detectable in DET-Enhanced SPPRs after $24 \mathrm{~h}$. As a general rule, when detectable chlorine residual was present in the influent to the SPPRs, levels were higher in the system with PEX after $10 \mathrm{~min}$ than in the equivalent system with copper, consistent with the overall hypothesis of this work and our prior research [25] (Figure 1).
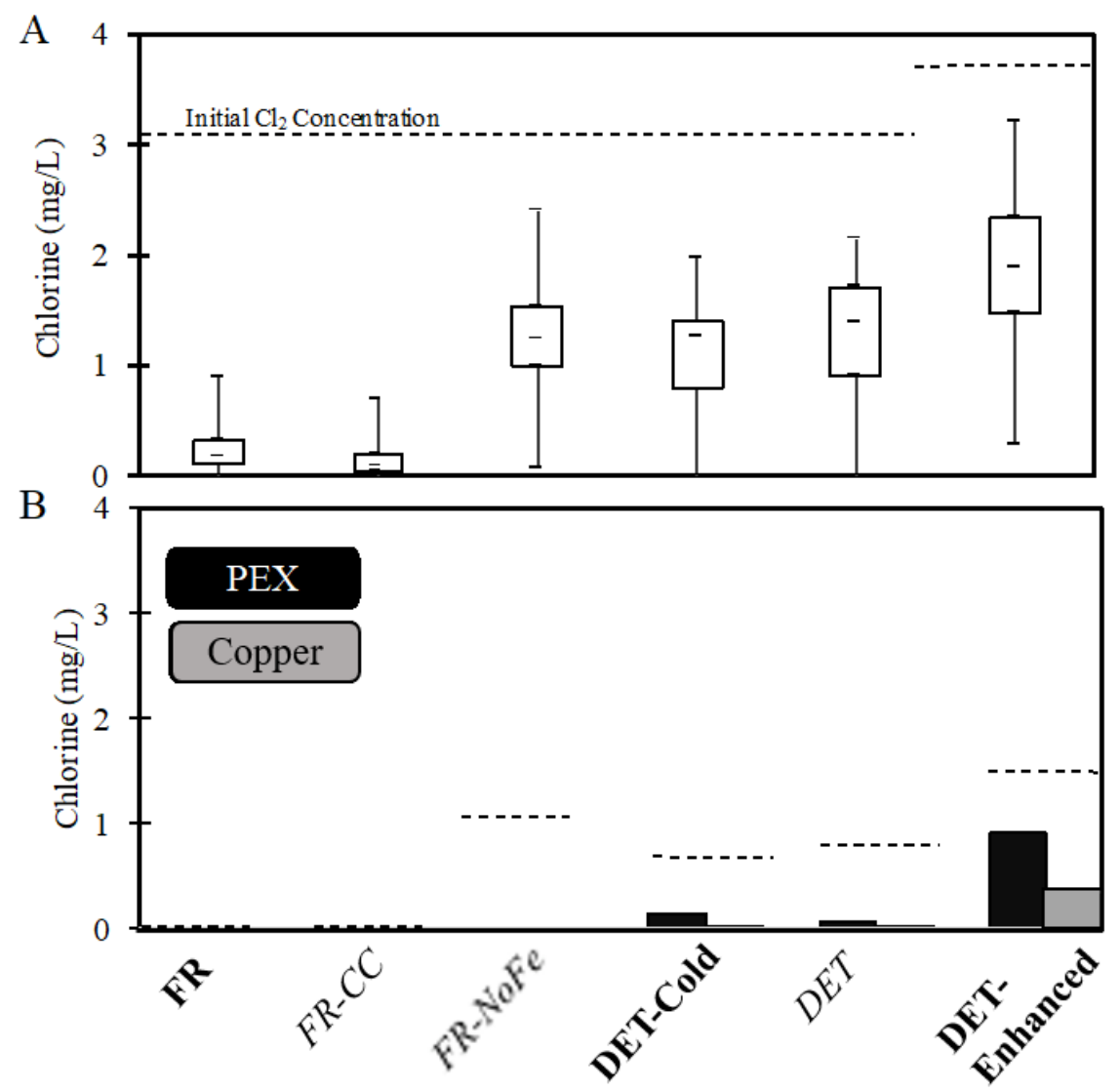

Figure 4. Chlorine residuals (A) after $3 \mathrm{~h}$ contact time in the simulated distribution systems (SDSs) and (B) $120 \mathrm{~min}$ after the effluent from the SDSs were fed to the simulated premise plumbing reactors (SPPRs) (50\% fresh SDSs water with 50\% remaining SDSs following incubation in the SPPRs the previous cycle). Dashed lines indicate the calculated initial chlorine level added for each water or reactor type. Bars represent the maximum and minimum, the upper and lower bounds of the box are the first and third quartiles, and the median is indicated by the internal dash. The detection limit was $0.02 \mathrm{mg} / \mathrm{L}$.

Overall, these results illustrate quick and drastic decay of the chlorine disinfectant residual in premise plumbing systems (Figure 4) that added to decay in the distribution systems (Figure 3). The U.S. Environmental Protection Agency (EPA) recommends that a free chlorine disinfectant residual be detectable (often, $>0.1$ or $>0.2 \mathrm{mg} / \mathrm{L}$ ) in $95 \%$ of distribution system samples [34], which has previously 
been acknowledged not to be adequate for the reduction of Legionella in large buildings, single-family homes, or small buildings [35]. The results from the Detroit tap water SPPRs (DET, DET-Cold, DET-Enhanced) demonstrate that the residual was detectable $\left(>0.1 \mathrm{mg} / \mathrm{L} \mathrm{Cl}_{2}\right)$ after $120 \mathrm{~min}$ in the SPPRs only when the disinfectant residual entering much higher than $0.2 \mathrm{mg} / \mathrm{L} \mathrm{Cl}_{2}$ (Figure 4).

\subsubsection{SPPRs Copper}

Mean total copper in influent water (Table 1B) to all SPPRs was consistently $<15 \mu \mathrm{g} / \mathrm{L}$ and mean effluent copper from PEX reactors was consistently $<100 \mu \mathrm{g} / \mathrm{L}$, in accordance with the assumption that the only source of copper was traces from plumbing used to collect well-flushed raw water samples in the field. However, SPPRs containing copper pipe consistently produced effluent with total mean copper concentrations $>700 \mu \mathrm{g} / \mathrm{L}$ (Table 1 section $\mathrm{C}$ ) and were statistically higher than the copper concentrations from the PEX SPPRs effluent $\left(p\right.$ value $\left.=2 \times 10^{-16}\right)$. Further, effluents from SPPRs receiving treated Flint River water, simulating Flint water during the crisis (FR), contained higher total copper than each of the corresponding conditions representing Detroit water (DET-Cold, DET-Enhanced, $p$ values $<4 \times 10^{-5}$ ), consistent with the lack of copper corrosion control during this time period. Thus, the laboratory simulation successfully reproduced the trends in copper levels characteristic of pre-/during and post-crisis conditions in Flint, where mean, 5th, and 95th percentiles of first draw copper during the crisis were approximately three times higher than post-crisis (Table 1 section $\mathrm{A}, \mathrm{C})$.

\subsection{Legionella pneumophila Response to Simulation of Water Chemistry and Premise Plumbing Material}

After 101 days of SPPRs acclimation to the SDSs water and the cross-inoculation period, culturable L. pneumophila numbers were greatest in SPPRs receiving treated Flint River waters, particularly the PEX condition (Figure 5A). Among all SPPRs containing PEX material, L. pneumophila CFU/mL were significantly higher in treated Flint River water-sourced (Figure 5A) compared to Detroit-sourced (Days 25-175; $p<0.05$; Figure 5C) water. This demonstrated the main hypothesized effect of treated Flint River water being more conducive than Detroit tap water to maintaining viable L. pneumophila, at least in the absence of copper pipe (Figure 1).

Throughout the study, L. pneumophila persisted at low numbers in the copper SPPRs fed with treated Flint River waters, but at levels significantly lower than in the PEX SPPRs ( $p$ value $=0.03$ ). In particular, the copper SPPRs receiving FR-NoFe influent water sustained little to no culturable L. pneumophila beyond 75 days (Figure 5B). During our field sampling at the height of the summer 2015 LD outbreak, the $\mathrm{pH}$ was 7.0 in Flint homes, in which case the higher acidity likely caused much higher levels of $\mathrm{Cu}^{+2}$ in premise plumbing $[3,12,14]$ than in this study at a $\mathrm{pH}$ of 7.8 . Together, the results from the treated Flint River water copper SPPRs at a pH 7.8 suggest that, under conditions of corrosive influent water (including the $F R-C C$ water as evidenced by chlorine decay tests; Figure 3B), the elevated copper concentrations can enhance reduction of L. pneumophila, consistent with the overarching hypotheses of this study (Figure 1).

The Detroit tap water conditions provide a simulation of what occurred before the city of Flint switched to the treated Flint River water (April 2014), and after they switched treated Flint River water back to the Detroit municipal water supply on 16 October 2015. Initial culturable counts of L. pneumophila declined under all Detroit tap water conditions within the first month (Figure 5C,D), which was consistent with our field data $[1,3]$ and the corresponding drop in LD incidence after switching back to Detroit water [5]. The loss of culturable L. pneumophila was greatest in PEX SPPRs for all three Detroit tap water SDS conditions, with culturable L. pneumophila falling below detection by Day 25, with a single exception (Figure 5C). Interestingly, L. pneumophila fared better in Detroit SPPRs containing copper pipe relative to those containing PEX pipe material, consistent with a previous study in the same Detroit tap water PEX reactors with no chlorine and additional mixing [12]. Plate counts in Detroit SPPRs containing copper remained near $1 \mathrm{CFU} / \mathrm{mL}$ from Day 25 until the end of the experiment. This suggests the additional chlorine demand and reduced chlorine levels caused by the 
presence of copper can actually increase growth of Legionella as hypothesized (Table 1 and Figure 1). Notably, the colony counts in the DET-Enhanced condition dropped below detection after just 100 days (Figure 5D), illustrating that extra chlorine can overcome the demand exerted by copper and more effectively control L. pneumophila. The presence of orthophosphate in Detroit tap water also would have reduced toxicity of the L. pneumophila to copper as reported in earlier studies [12,24,36].

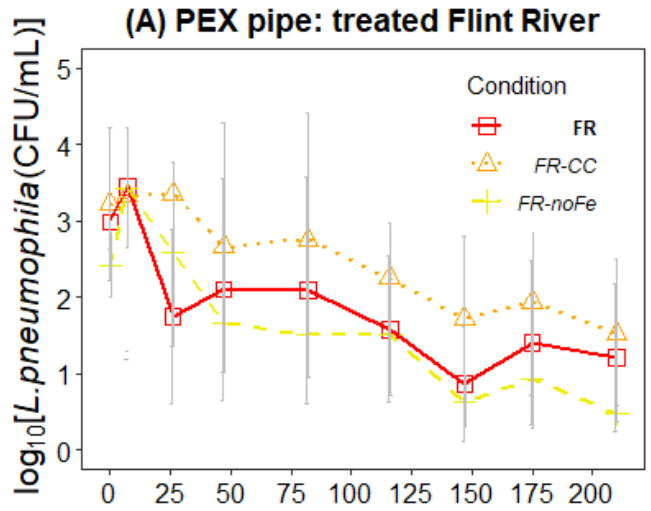

(B) Copper pipe: treated Flint River

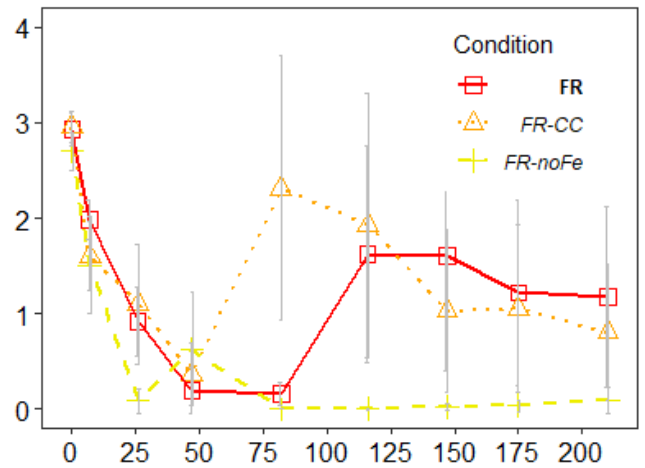

(D) Copper pipe: Detroit tap
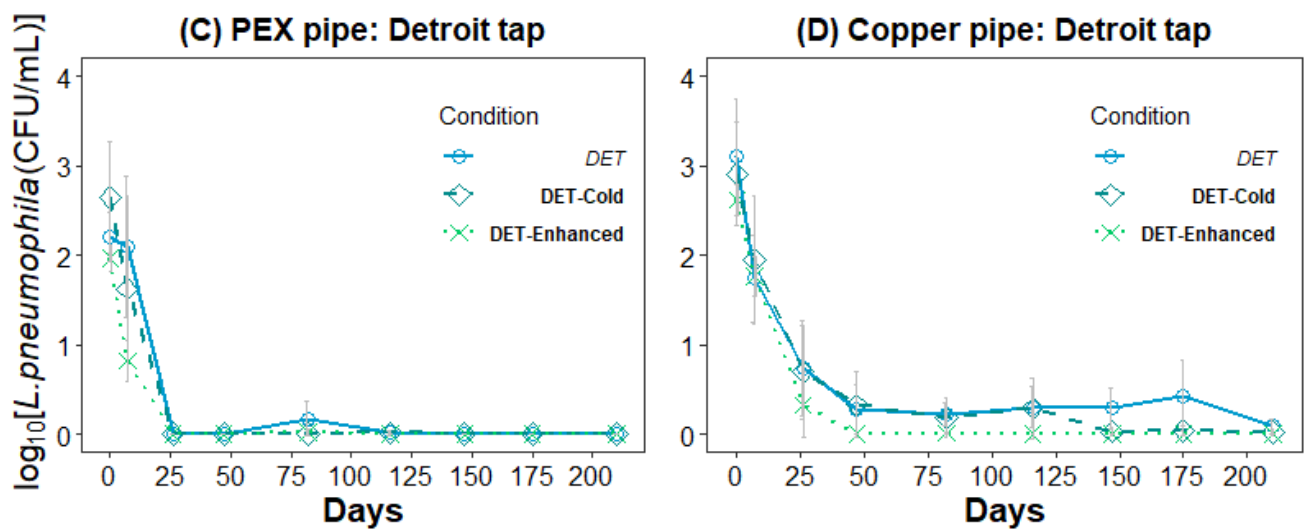

Figure 5. The effects of water source, distribution conditions, and pipe material on culturable L. pneumophila in simulated premise plumbing reactors (SPPRs). Effluent log transformed average L. pneumophila numbers $(\mathrm{CFU} / \mathrm{mL})$ and standard deviations from SPPRs receiving simulated distribution system (SDS) water corresponding to: (A) treated Flint River water with PEX pipe coupons; (B) treated Flint River water with copper pipe coupons; (C) Detroit tap water with PEX pipe coupons; and (D) Detroit tap water with copper pipe coupons. All SPPRs influent waters were spiked to an initial target concentration of $3 \mathrm{mg} \mathrm{Cl} / \mathrm{L}$ and aged three hours under completely-mixed conditions at $23{ }^{\circ} \mathrm{C}$ in the presence of an iron wire (SDS step), except $F R$-NoFe conditions, which had no iron wire, and DET-Cold condition, which was incubated at $17^{\circ} \mathrm{C}$. FR-CC additional orthophosphate corrosion control agent added at $1 \mathrm{mg} / \mathrm{L}$, DET-Enhanced additional $\mathrm{CL}_{2}$ added at $3.5 \mathrm{mg} / \mathrm{L}$ and orthophosphate at $2.5 \mathrm{mg} / \mathrm{L}$.

\subsubsection{Isolate Analysis}

To gain insight into whether a single strain or mixture of strains of Legionella persisted under the various conditions, 56 representative isolates collected from the SPPRs on Days 0, 47, 82, 175, and 210 were subject to genotypic screening by PCR. Interestingly, it was observed that L. pneumophila survived through the end of the experiment across all simulations, except DET-Enhanced (Table S1). Of the L. pneumophila strains recovered from SPPRs fed with treated Flint River water by Day 150, 56/56 were characterized as serogroup 1. By Day 210, FR and all other water conditions supporting Legionella were confirmed to contain a mixture of serogroup 1 and non-serogroup 1 L. pneumophila, based on PCR detection of the wzm gene. The ability to multiple serogroups of L. pneumophila to persist under the various conditions of this experiment suggests that the trends observed in response to the water conditions employed in this study were robust across multiple serogroups. 


\subsubsection{Chlorine Disinfectant}

Chlorine is by far the most widely implemented and relied upon secondary disinfectant residual applied in the U.S. and around the world. Previous studies have indicated that concentrations $>0.5 \mathrm{mg} / \mathrm{L}$ are sometimes sufficient for limiting detectable levels of Legionella in large building plumbing water systems $[37,38]$. As demonstrated above, once added to SPPRs, chlorine concentrations immediately decreased and were often no longer detectable after $60 \mathrm{~min}$ following a water change. Further, in all SPPRs, except those receiving DET-Enhanced water, chlorine concentrations decreased below $0.5 \mathrm{mg} / \mathrm{L}$ within the first $10 \mathrm{~min}$. The persistence of culturable Legionella in all conditions, except the DET-Enhanced, essentially proves that adequate disinfection was not achieved for the other 10 conditions

\subsubsection{Pipe Material: PEX and Copper}

Comparing copper versus PEX pipe materials further illustrated the potential for premise plumbing conditions to mediate the effects of the distribution system water chemistry. Copper is of particular interest because of its known antimicrobial properties towards L. pneumophila [28,39-41]. Ironically, the lack of corrosion control, which triggered higher iron and lower chlorine residuals and exacerbated Legionella problems in some portions of the Flint distribution system during the crisis [3], also released high levels of copper that might have helped to control Legionella growth in some buildings and homes. In this study, regardless of influent water sources, copper SPPRs displayed rapid initial loss of culturable L. pneumophila subsequent to feeding the SDS waters. However, low colony counts persisted in most SPPR conditions containing copper at the higher $\mathrm{pH}$, representative of the summer 2014 outbreak, for nearly six months. The initial reduction of Legionella CFUs in copper SPPRs may have occurred through limited antimicrobial properties of aged copper at the relatively high $\mathrm{pH}$ employed in this study, as observed by others $[12,24,42,43]$.

As Legionella are facultative intracellular bacteria, they are capable of residing in biofilms and replicating in more than 20 species of amoebae [44,45]. In harsh environments, such as the surface of copper pipe material or variable disinfection levels of chlorine, existing biofilms may serve as a protective environment for Legionella to shelter from disinfectants [26,43,45]. However, this study suggests that such protective mechanisms can be overcome by higher chlorine residual and contact time. This is demonstrated by the DET-Enhanced copper condition, which included increased chlorine and corrosion control agent and contained no culturable L. pneumophila from Day 50 forward (with the exception of a single colony obtained from a $50 \mathrm{~mL}$ sample of water on Day 82) (Figure 5D).

Interactions between copper and influent chlorine residuals may provide an environment that allows for the persistence of Legionella in premise plumbing, especially if corrosion control maintains $\mathrm{Cu}^{+2}$ below thresholds controlling Legionella $[14,19,46]$. A previous study determined that disinfectant potential of free chlorine can be affected by the age of copper pipe material [28]. In both treated Flint River water and Detroit tap water, the presence of aged copper reduced the capacity of the SPPRs to maintain measurable free chlorine residuals (Figure 5B), but the presence of orthophosphate corrosion control may have allowed Legionella to persist at higher levels in DET or DET-Cold water, whereas the corresponding condition with higher copper in FR helped reduce Legionella.

\subsection{Experimental Conditions: Hypothetical Effects of Stagnation, Chlorine, and Elevated $p H$}

Comparing results of the current study to those obtained to those from a companion study using the same SPPRs, but with continuous mixing, slightly lower $\mathrm{pH}$, and no disinfectants (Figure 6) [12] can provide insight into overarching effects of experimental conditions selected for this study. Notably, L. pneumophila in the treated Flint River water with PEX was 2.5-log higher in the previous study. We hypothesize that this is attributable to continuous mixing versus stagnation, since the small $\mathrm{pH}$ change is not expected to be influential for PEX, and chlorine levels delivered to this reactor from the SDSs in this work were consistently undetectable. A much smaller increase of 0.4-1.0 log was 
observed for treated Flint River water copper conditions in the prior study versus this work, mostly likely due to the lower $\mathrm{pH}$ significantly enhancing bacteriostatic impacts of cupric ion. In any case, the higher L. pneumophila with more mixing is consistent with prior results in recirculating versus non-recirculating systems $[17,19,47,48]$ in which there were warm temperatures and low disinfectant residuals. In Detroit tap water conditions, comparable conditions between the two studies consistently led to non-detectable L. pneumophila, except for copper pipe with both mixing and corrosion control, where relatively low levels of L. pneumophila persisted.
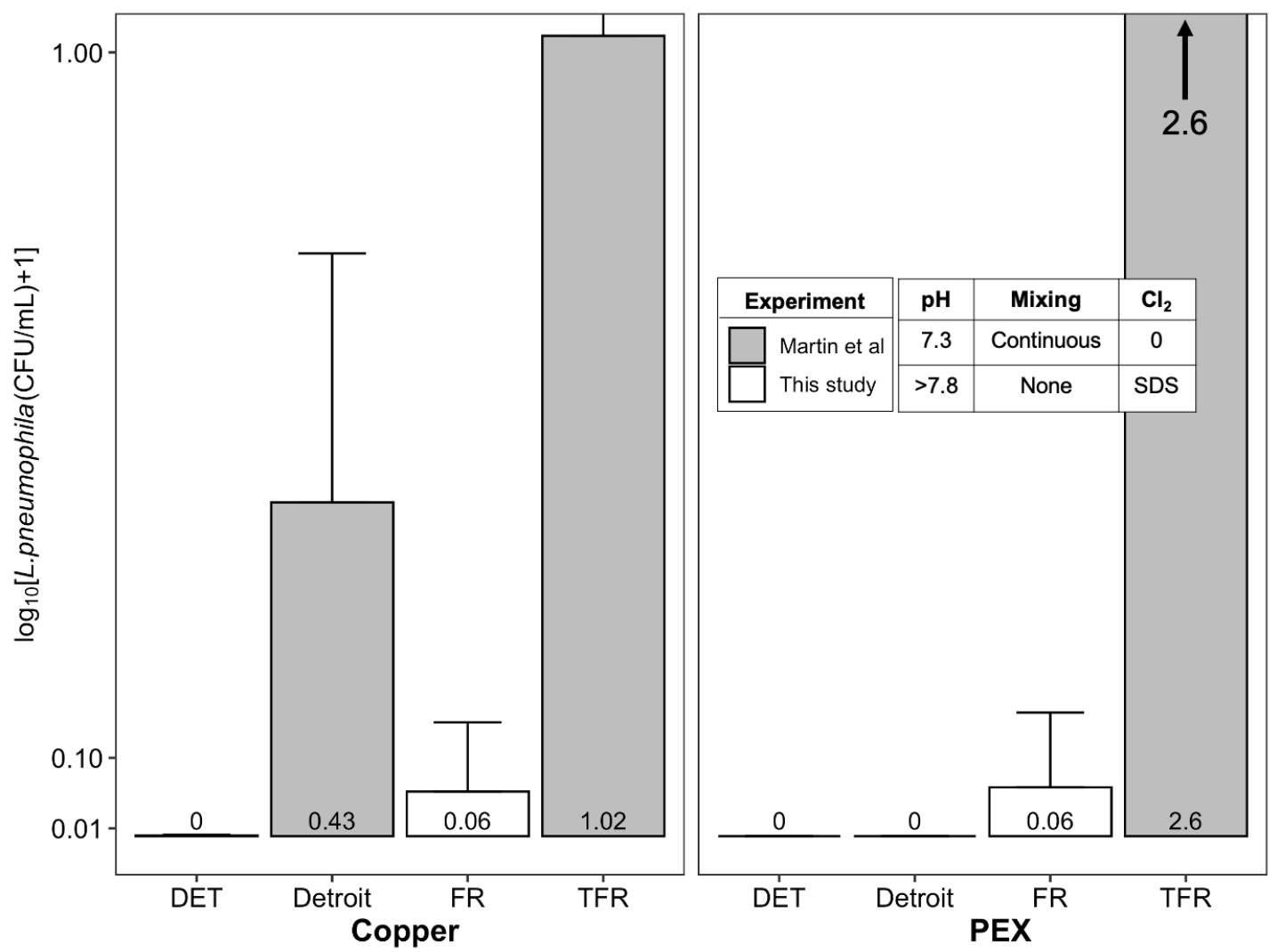

Figure 6. Comparison of culturable L. pneumophila (CFU/mL) from control reactors in this study (Day 210 samples only) compared to Martin et al. (sampled at one year). Each bar in the plot represents the average of triplicate reactors with the error bars showing the standard deviation. The Detroit condition contained the same influent as DET, with no iron and $2.5 \mathrm{mg} / \mathrm{L}$ of orthophosphate. The treated Flint River (TFR) condition contained the same influent as FR except without the iron aging step.

\section{Conclusions}

The findings of this study are consistent with the understanding that L. pneumophila is not uncommon in municipal water flowing into buildings [49], but a range of water chemistry and premise plumbing conditions and disinfectant residuals can prevent their proliferation. Persistent disinfectant, including chlorine, is known to be a critical factor in reducing Legionella risk [35,37,39], and a recent study confirmed predicted associations between low levels of chlorine in Flint's distribution system and observed incidence of LD [5]. Consistent with our prior in-field observations [1,3], we further demonstrate under controlled laboratory conditions the importance of considering interactive effects with flow and pipe materials, particularly with respect to relative water corrosivity and influence on residual chlorine levels, in keeping Legionella levels low. Indeed, many individual factors can act as "two-edged swords" in terms of their net effect of controlling versus enhancing Legionella growth, depending on the status of other factors. For example, copper pipe achieves its best antimicrobial efficacy without corrosion control, but absence of corrosion control also leads to elevated iron and depleted chlorine residual, which in turn enhance Legionella growth. Such interactive effects can help 
explain why prior studies reported relatively low levels of Legionella in single family homes, which tend to have greater stagnation and more copper in water from copper service lines and plumbing, compared to large multi-story buildings during the Flint Water Crisis.

Supplementary Materials: The following are available online at http://www.mdpi.com/2076-0817/9/9/730/s1, Table S1: PCR confirmation of unique morphologies that were identified morphologically as Legionella.

Author Contributions: Conceptualization, O.R.S., M.A.E., and A.P.; methodology, O.R.S., M.A.E., and A.P.; software, O.R.S. and R.L.M.; validation, O.R.S. and R.L.M.; formal analysis, R.L.M. and O.R.S.; investigation, O.R.S., R.L.M., M.A.E., and A.P.; resources, O.R.S.; data curation, R.L.M. and O.R.S.; writing-original draft preparation, R.L.M., O.R.S., M.A.E. and A.P.; writing - review and editing, O.R.S., R.L.M., M.A.E., and A.P.; visualization, O.R.S. and R.L.M.; supervision, M.A.E. and A.P.; project administration, M.A.E. and A.P.; and funding acquisition, M.A.E. and A.P. All authors have read and agreed to the published version of the manuscript.

Funding: This research was funded by National Science Foundation for CBET via Awards 1336650, 1556258, and 1706733. The Alfred P. Sloan Foundation Microbiology of the Built Environment Program, and the Science and Engineering of the Exposome (SEE) Center supported by the Institute for Critical Technology and Applied Science at Virginia Tech, also provided financial support on this project.

Acknowledgments: We would like to thank Stephen Wolbert and LeeAnne Walters for their cooperation in collecting and shipping Flint water, as well as Laurel Strom, D. Otto Schwake, Emily Garner, Jacob Seymour, and Jeffrey Parks for their technical and laboratory assistance, and the Virginia Tech Library Open Access Subvention Fund.

Conflicts of Interest: The authors declare no conflict of interest.

\section{References}

1. Schwake, D.O.; Garner, E.; Strom, O.R.; Pruden, A.; Edwards, M.A. Legionella DNA Markers in Tap Water Coincident with a Spike in Legionnaires' Disease in Flint, MI. Environ. Sci. Technol. Lett. 2016, 3, 311-315. [CrossRef]

2. Pieper, K.J.; Tang, M.; Edwards, M.A. Flint Water Crisis Caused By Interrupted Corrosion Control: Investigating “Ground Zero" Home. Environ. Sci. Technol. 2017, 51, 2007-2014. [CrossRef] [PubMed]

3. Rhoads, W.J.; Garner, E.; Ji, P.; Zhu, N.; Parks, J.; Schwake, D.O.; Pruden, A.; Edwards, M.A. Distribution System Operational Deficiencies Coincide with Reported Legionnaires' Disease Clusters in Flint, MI. Environ. Sci. Technol. 2017, 51, 11986-11995. [CrossRef] [PubMed]

4. Masten, S.J.; Davies, S.H.; Mcelmurry, S.P. Flint Water Crisis: What Happened and Why? J. Awwa 2016, 108, 22-34. [CrossRef]

5. Zahran, S.; McElmurry, S.P.; Kilgore, P.E.; Mushinski, D.; Press, J.; Love, N.G.; Sadler, R.C.; Swanson, M.S. Assessment of the Legionnaires' disease outbreak in Flint, Michigan. Proc. Natl. Acad. Sci. USA 2018. [CrossRef]

6. Smith, A.F.; Huss, A.; Dorevitch, S.; Heijnen, L.; Arntzen, V.H.; Davies, M.; Robert-Du Ry van Beest Holle, M.; Fujita, Y.; Verschoor, A.M.; Raterman , B.; et al. Sources of the Outbreak of Legionnaires' Disease in Genesee County, Michigan, in 2014 and 2015. Environ. Health Perspect. 2019, 127, 127001. [CrossRef]

7. Garrison, L.E. Vital Signs: Deficiencies in Environmental Control Identified in Outbreaks of Legionnaires' Disease-North America, 2000-2014. Mmwr. Morb. Mortal. Wkly. Rep. 2016, 65.

8. Proctor, C.R.; Dai, D.; Edwards, M.A.; Pruden, A. Interactive effects of temperature, organic carbon, and pipe material on microbiota composition and Legionella pneumophila in hot water plumbing systems. Microbiome 2017, 5, 130. [CrossRef]

9. Williams, K.; Pruden, A.; Falkinham, J.O.; Edwards, M. Relationship between Organic Carbon and Opportunistic Pathogens in Simulated Glass Water Heaters. Pathogens 2015, 4, 355-372. [CrossRef]

10. Wang, H.; Masters, S.; Falkinham, J.O.; Edwards, M.A. Distribution System Water Quality Affects Responses of Opportunistic Pathogen Gene Markers in Household Water Heaters. Environ. Sci. Technol. 2015, 49, 8416-8424. [CrossRef]

11. Michigan Department of Human and Health Services (MDHHS). MDHHS Response to Flint Area Community Health and Environment Partnership Proceedings of the National Academy of Sciences Article. 2018. Available online: https:/content.govdelivery.com/attachments/MIDHHS/2018/02/05/file_attachments/953946/

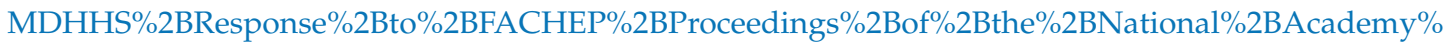
2Bof\%2BSciences\%2BArticle\%2BFINAL.pdf (accessed on 3 September 2020). 
12. Martin, R.L.; Strom, O.R.; Song, Y.; Mena-Aguilar, D.; Rhoads, J.W.; Pruden, A.; Edwards, M. Copper Pipe, Lack of corrosion control, and uncontrolled $\mathrm{pH}$ influenced the trajectory of the Flint Legionnaires' Disease outbreak. Environ. Sci. Technol. (under review).

13. Ji, P.; Parks, J.; Edwards, M.A.; Pruden, A. Impact of Water Chemistry, Pipe Material and Stagnation on the Building Plumbing Microbiome. PLoS ONE 2015, 10, e0141087. [CrossRef] [PubMed]

14. Lin, Y.-s.E.; Vidic, R.D.; Stout, J.E.; Victor, L.Y. Negative effect of high $\mathrm{pH}$ on biocidal efficacy of copper and silver ions in controlling Legionella pneumophila. Appl. Environ. Microbiol. 2002, 68, 2711-2715. [CrossRef] [PubMed]

15. Zhang, Y.; Griffin, A.; Edwards, M. Nitrification in premise plumbing: Role of phosphate, $\mathrm{pH}$ and pipe corrosion. Environ. Sci. Technol. 2008, 42, 4280-4284. [CrossRef] [PubMed]

16. Liu, Z.; Lin, Y.E.; Stout, J.E.; Hwang, C.C.; Vidic, R.D.; Yu, V.L. Effect of flow regimes on the presence of Legionella within the biofilm of a model plumbing system. J. Appl. Microbiol. 2006, 101, 437-442. [CrossRef] [PubMed]

17. Rhoads, W.J.; Ji, P.; Pruden, A.; Edwards, M.A. Water heater temperature set point and water use patterns influence Legionella pneumophila and associated microorganisms at the tap. Microbiome 2015, 3, 1-13. [CrossRef]

18. Shen, Y.; Guillermo, L.M.; Nicolas, D.; Dao, J. Role of Biofilm Roughness and Hydrodynamic Conditions in Legionella pneumophila Adhesion to and Detachment from Simulated Drinking Water Biofilms. Environ. Sci. Technol. 2015, 49, 4274. [CrossRef]

19. Mathys, W.; Stanke, J.; Harmuth, M.; Junge-Mathys, E. Occurrence of Legionella in hot water systems of single-family residences in suburbs of two German cities with special reference to solar and district heating. Int. J. Hyg. Environ. Health 2008, 211, 179-185. [CrossRef]

20. Rhoads, W.; Pruden, A.; Edwards, M. Convective Mixing in Distal Pipes Exacerbates Legionella pneumophila Growth in Hot Water Plumbing. Pathogens 2016, 5, 29. [CrossRef]

21. Mouchtouri, V.A.; Goutziana, G.; Kremastinou, J.; Hadjichristodoulou, C. Legionella species colonization in cooling towers: Risk factors and assessment of control measures. Am. J. Infect. Control 2010, 38, 50-55. [CrossRef]

22. Kim, B.R.; Anderson, J.E.; Mueller, S.A.; Gaines, W.A.; Kendall, A.M. Literature review—efficacy of various disinfectants against Legionella in water systems. Water Res. 2002, 36, 4433-4444. [CrossRef]

23. Muraca, P.; Stout, J.E.; Yu, V.L. Comparative assessment of chlorine, heat, ozone, and UV light for killing Legionella pneumophila within a model plumbing system. Appl. Environ. Microbiol. 1987, 53, 447-453. [CrossRef] [PubMed]

24. Nguyen, C.; Elfland, C.; Edwards, M. Impact of advanced water conservation features and new copper pipe on rapid chloramine decay and microbial regrowth. Water Res. 2012, 46, 611-621. [CrossRef] [PubMed]

25. Nguyen, C.K.; Powers, K.A.; Raetz, M.A.; Parks, J.L.; Edwards, M.A. Rapid free chlorine decay in the presence of $\mathrm{Cu}(\mathrm{OH})_{2}$ : Chemistry and practical implications. Water Res. 2011, 45, 5302-5312. [CrossRef] [PubMed]

26. Zheng, M.; He, C.; He, Q. Fate of free chlorine in drinking water during distribution in premise plumbing. Ecotoxicology 2015, 24, 2151-2155. [CrossRef] [PubMed]

27. Dai, D.; Proctor, C.R.; Williams, K.; Edwards, M.A.; Pruden, A. Mediation of effects of biofiltration on bacterial regrowth, Legionella pneumophila, and the microbial community structure under hot water plumbing conditions. Environ. Sci. Water Res. Technol. 2018, 4, 183-194. [CrossRef]

28. Merault, N.; Rusniok, C.; Jarraud, S.; Gomez-Valero, L.; Cazalet, C.; Marin, M.; Brachet, E.; Aegerter, P.; Gaillard, J.; Etienne, J. Specific real-time PCR for simultaneous detection and identification of Legionella pneumophila serogroup 1 in water and clinical samples. Appl. Environ. Microbiol. 2011, 77, 1708-1717. [CrossRef]

29. Kozak, N.A.; Benson, R.F.; Brown, E.; Alexander, N.T.; Taylor, T.H.; Shelton, B.G.; Fields, B.S. Distribution of lag-1 alleles and sequence-based types among Legionella pneumophila serogroup 1 clinical and environmental isolates in the United States. J. Clin. Microbiol. 2009, 47, 2525-2535. [CrossRef]

30. Flint Water Treatment Plant. Monthly Operating Reports. Available online: https://www.michigan.gov/ flintwater/0,6092,7-345-76292_76364-377816--,00.html (accessed on 28 January 2020).

31. Miller, C.M.; Bower, K.C. Iron Oxide Enhanced Chlorine Decay and Disinfection By-Product Formation. J. Environ. Eng. 2006, 132, 1609-1616. [CrossRef] 
32. McNeill, L.S.; Edwards, M. Iron pipe corrosion in distribution systems. J. Am. Water Work. Assoc. 2001, 93, 88-100. [CrossRef]

33. McNeill, L.S.; Edwards, M. Phosphate inhibitor use at US utilities. J. Am. Water Work. Assoc. 2002, 94, 57-63. [CrossRef]

34. Wahman, D.G.; Pressman, J.G. Distribution System Residuals-Is "Detectable" Still Acceptable for Chloramines? J. Awwa 2015, 107, 53-63. [CrossRef]

35. National Academies of Sciences and Engineering. Management of Legionella in Water Systems; The National Academies Press: Washington, DC, USA, 2019. [CrossRef]

36. Lin, Y.E.; Vidic, R.D. Possible phosphate interference with copper-silver ionization for Legionella control. J. Hosp. Infect. 2006, 62, 119. [CrossRef] [PubMed]

37. Orsi, G.B.; Vitali, M.; Marinelli, L.; Ciorba, V.; Tufi, D.; Del Cimmuto, A.; Ursillo, P.; Fabiani, M.; De Santis, S.; Protano, C.; et al. Legionella control in the water system of antiquated hospital buildings by shock and continuous hyperchlorination: 5 years experience. Bmc Infect. Dis. 2014, 14, 394. [CrossRef] [PubMed]

38. Alary, M.; Joly, J.R. Factors contributing to the contamination of hospital water distribution systems by Legionellae. J. Infect. Dis. 1992, 165, 565-569. [CrossRef] [PubMed]

39. Rhoads, W.J.; Pruden, A.; Edwards, M.A. Interactive Effects of Corrosion, Copper, and Chloramines on Legionella and Mycobacteria in Hot Water Plumbing. Environ. Sci. Technol. 2017. [CrossRef]

40. Triantafyllidou, S.; Lytle, D.; Muhlen, C.; Swertfeger, J. Copper-silver ionization at a US hospital: Interaction of treated drinking water with plumbing materials, aesthetics and other considerations. Water Res. 2016, 102, 1-10. [CrossRef]

41. Lin, Y.E.; Stout, J.E.; Vidic, R.D. Disinfection of water distribution systems for Legionella. Semin. Respir. Infect. 1998, 13, 147-159.

42. Van der Kooij, D.; Veenendaal, H.R.; Scheffer, W.J.H. Biofilm formation and multiplication of Legionella in a model warm water system with pipes of copper, stainless steel and cross-linked polyethylene. Water Res. 2005, 39, 2789-2798. [CrossRef]

43. Gião, M.S.; Wilks, S.A.; Keevil, C.W. Influence of copper surfaces on biofilm formation by Legionella pneumophila in potable water. Biometals 2015, 28, 329. [CrossRef]

44. Falkinham, J.O.; Pruden, A.; Edwards, M. Opportunistic Premise Plumbing Pathogens: Increasingly Important Pathogens in Drinking Water. Pathogens 2015, 4, 373-386. [CrossRef] [PubMed]

45. Lau, H.; Ashbolt, N. The role of biofilms and protozoa in Legionella pathogenesis: Implications for drinking water. J. Appl. Microbiol. 2009, 107, 368-378. [CrossRef] [PubMed]

46. Buse, H.Y.; Lu, J.; Struewing, I.T.; Ashbolt, N.J. Preferential colonization and release of Legionella pneumophila from mature drinking water biofilms grown on copper versus unplasticized polyvinylchloride coupons. Int. J. Hyg. Environ. Health 2014, 217, 219. [CrossRef] [PubMed]

47. Bédard, E.; Paranjape, K.; Lalancette, C.; Villion, M.; Quach, C.; Laferrière, C.; Faucher, S.P.; Prévost, M. Legionella pneumophila levels and sequence-type distribution in hospital hot water samples from faucets to connecting pipes. Water Res. 2019, 156, 277-286. [CrossRef] [PubMed]

48. Moore, M.R.; Pryor, M.; Fields, B.; Lucas, C.; Phelan, M.; Besser, R.E. Introduction of monochloramine into a municipal water system: Impact on colonization of buildings by Legionella spp. Appl. Environ. Microbiol. 2006, 72, 378-383. [CrossRef]

49. Donohue, M.J.; O'Connell, K.; Vesper, S.J.; Mistry, J.H.; King, D.; Kostich, M.; Pfaller, S. Widespread Molecular Detection of Legionella pneumophila Serogroup 1 in Cold Water Taps across the United States. Environ. Sci. Technol. 2014, 48, 3145-3152. [CrossRef]

(C) 2020 by the authors. Licensee MDPI, Basel, Switzerland. This article is an open access article distributed under the terms and conditions of the Creative Commons Attribution (CC BY) license (http://creativecommons.org/licenses/by/4.0/). 